\title{
MORAL TRANSGRESSION, DISEASE AND HOLISTIC HEALTH IN THE LIVINGSTONIA MISSION IN LATE NINETEENTH AND EARLY TWENTIETH-CENTURY MALAWI'1
}

\author{
Markku Hokkanen
}

University of Jyväskylä

\begin{abstract}
This article examines ideas of morality and health, and connections between moral transgression and disease in both Scottish missionary and Central African thought in the context of the Livingstonia Mission of the Presbyterian Free Church of Scotland in Malawi during the late nineteenth and early twentieth centuries. ${ }^{2}$ By concentrating on debates, conflicts and co-operation bet-
\end{abstract}

1 An early version of this article was presented at the European Social Science History Conference in Amsterdam, March 2006. I would like to thank the organizers of the ESSHC and the Health-network, my fellow panelists Jari Eilola, Alaric Hall and Douglas Aitken, as well as all the participants in a fruitful and thought-provoking session. I would also like to thank Anssi Halmesvirta, J.A. Mangan, John McCracken and Kings M. Phiri. Parts of the article have been previously published in HoKKANEN, M. (2007a), Medicine and Scottish Missionaries in the Northern Malawi Region 1875-1930. Quests for Health in a Colonial Society, Lewiston, The Edwin Mellen Press. I remain grateful to the Department of History and Ethnology, University of Jyväskylä, as well as the Emil Aaltonen Foundation, for supporting my research and participation in the ESSHC conference.

2 Livingstonia, founded in 1875 as a tribute to David Livingstone, was one of the largest and best-known Protestant missions in Central Africa before the First World War. At its zenith, the mission's sphere of influence extended from present-day Malawi (known as the Nyasaland Protectorate from 1907 until 1964) to Zambia (Northern Rhodesia). It was estimated that the Livingstonia wielded some influence across a region the size of England and Wales. This vast area boasted eight principal mission stations by 1914, a number of smaller stations and over a hundred mission schools, where pupils were taught by African teachers. The total number of church members in full communion grew from about 1,500 in 1901 to over 10,000 in 1915. The Scottish missionaries and their wives numbered about forty-five in the early twentieth century, when the Scottish presence was at its strongest. Furthermore, the mission employed hundreds of African teachers, evangelists, preachers and eventually a handful of the first African pastors to be ordained. For the history of the mission, see MCCRACKEN, J. (2000 [1977]), Politics and Christianity in Malawi 1875-1940. The Impact of Livingstonia Mission in the Northern Province, Blantyre, CLAIM. 
ween missionaries and Africans over the key issues of beer drinking and sexual morality, this article explores the emergence of a new 'moral hygiene' among African Christian communities in Northern Malawi.

KEY WORDS: Alcohol. Christian missions. Health. Livingstonia. Malawi. Moral hygiene. Sexuality.

\section{TRANSGRESSION MORAL, ENFERMEDAD Y SALUD HOLÍSTICA EN LA MISIÓN LIVINGSTONIA EN MALAWI A FINALES DEL SIGLO XIX Y PRINCIPIOS DEL SIGLO XX}

\section{RESUMEN}

Este artículo analiza las ideas sobre moralidad y salud, así como las relaciones entre transgresión moral y enfermedad, tanto en el pensamiento misionero escocés como en el pensamiento del África central, en el contexto de la Misión de Livingstonia de la Iglesia Libre Presbiteriana de Escocia en Malawi entre finales del siglo XIX y principios del XX. Centrándose en las conversaciones, los conflictos y la colaboración entre los misioneros y los africanos sobre cuestiones clave como el consumo de cerveza y la moralidad sexual, este artículo estudia la aparición de una nueva «higiene moral» entre las comunidades cristianas africanas en Malawi del norte.

PALABRAS CLAVE: Alcohol. Misiones cristianas. Salud. Livingstonia. Malawi. Higiene moral. Sexualidad.

\section{THE THEORY OF HOLISTIC HEALTH IN LIVINGSTONIA}

For missionary doctor Robert Laws, the long-serving leader of Livingstonia, the moral health of an individual was determined by nerves, mind, spirit and character, all of which were inseparably intertwined. This belief underpinned the missionary programme of 'regeneration', which combined Victorian medical theory with evangelical moralism in an attempt to create a healthy Christian community. As Charles Rosenberg has noted, early nineteenthcentury Western theories of health and disease were holistic: health was negotiated by the individual's body and mind in interaction. Education, morality and emotions influenced decision-making, but volition and responsibility were at the heart of the speculative model of disease causation. Thus, medical theories strongly supported the existing Christian connection between sin and sickness until the 1860s. However, during the last third of the century the delicate balance between speculative mechanism and moral responsibility was disturbed through medical debates. The late Victorian period witnessed both the increasingly materialistic and reductionist framing of psychosomatic diseases and the emergence of Christian faith healing. Whilst scientifically minded physicians, especially neurologists, sought to identify underlying 
biological mechanisms that would explain all disorders, proponents of faith healing followed the holistic theory of health to the conclusion that the soul ruled the mind and the mind ruled the body. ${ }^{3}$ Laws - who undertook his medical and theological studies at a time when these debates over mind and body were becoming increasingly intense- must be understood in this context.

In his sermons to fellow missionaries in 1883 (after seven years in Central Africa that had been marked by high rates of mortality and morbidity) Dr. Laws emphasized that physical illness sometimes affected the judgement of missionaries. Moral judgement was, after all, located in the mind, which was inseparably connected to the condition of the body. How, then, were missionaries, who were often seriously ill, to judge others? For Laws, the only solution was to become like Christ. A careful study of His life had shown Laws that Christ was a perfect, healthy man. ${ }^{4}$ Thus, in order to be Christ-like a missionary had to maintain his personal (masculine) health and be able to judge others without succumbing to the adverse influences of mental and bodily illhealth. This was the ideal to which Laws aspired, and which he believed was the ideal for all missionaries in Africa. In this respect, Laws's thought can be likened to the ideas of perfectionism prevalent in nineteenth-century Protestantism on both sides of the Atlantic. The perfection of body, mind and spirit was connected to the 'gospel of health' which sought to create perfect men and women. ${ }^{5}$ The Scottish Liberal Theology of the 1880s and 1890s placed significant emphasis on the historical figure of Jesus and the Kingdom of God as preached by Him. This contributed to the use of Biblical insights in social reform, especially within Laws's denomination, the United Presbyterian Church. ${ }^{6}$ For Laws, the realization of the Kingdom of God in the world meant the creation of a society that was both spiritually and physically healthy.

Laws believed that God would educate men in 'His ways', which were complex but governed by simple laws and principles. Many of these were revealed in the Bible; others were to be discovered through science: God

3 Rosenberg, C.E. (1989), Body and Mind in Nineteenth-Century Medicine: Some Clinical Origins of the Neurosis Construct, Bulletin of the History of Medicine, 63, pp. 195-196.

4 Sermon IX, 4 March 1883; Sermon XXII, 10 June 1883. Malawi National Archives (hereafter MNA) 47/LIM/4/11.

5 For ideas of perfectionism in Protestant thought in North America, see OpP, J.W. (2000), Religion, Medicine and the Body: Protestant Faith Healing in Canada, Ph.D. thesis, Department of History, Carleton University, pp. 41-43. Perfectionism and the search for holiness were closely connected to temperance and hygienic movements of the late nineteenth century.

6 CheYne, A.C. (1983), The Transforming of the Kirk, Victorian Scotland's Religious Revolution, Edinburgh, Saint Andrews Press, pp. 137-139. 
taught mankind through the Bible and the 'book of nature'. ${ }^{7}$ Laws believed that both the spiritual and the physical spheres of the world operated according to a set of rules and laws. Crucially, the concept of energy linked the material and spiritual worlds. For instance, Laws argued that when endowed with God's saving faith people could accomplish mighty physical deeds. He likened the influence of religious spirit in the body to the experience of individuals who 'survived wounds that would kill a dozen men'. In such cases, the spirit was 'putting forth its energy' and thus enhanced men's physical capacities. Just as the spiritual could influence the physical through energy, the physical could likewise influence the spiritual, as was evident in cases of physical illness and lack of energy. ${ }^{8}$

Alongside energy and nervous power, will power was a key concept in Laws's understanding of mental and moral health. Alcohol and narcotics were considered poisons because they weakened man's will. ${ }^{9}$ Narcotics paralysed and disabled the conscience, will and mental faculties of an individual and thus prevented him from recognizing his sins and seeking redemption and regeneration..$^{10}$ For Laws, sexual desire presented one of the greatest dangers to mental and moral health, and he advocated strict self-control and the exercise of will power to combat its influence. ${ }^{11}$ Energy, will power and nervous power linked the physical and the spiritual side of man: physiologically in the

7 Sermon XIII, 1 April 1883. MNA 47/LIM/4/11.

8 Sermon XXVIII, 29 July 1883. MNA 47/LIM/4/11; HoKkANEN, M. and Mangan, J.A. (2006), Further Variations on a Theme: The Games Ethic Further Adapted - Scottish Moral Missionaries and Muscular Christians in Malawi, The International Journal of the History of Sport, 23 (8), pp. 1257-1274, pp. 1263-1265.

9 It is revealing that in the late 1920 s Laws believed that $\sin$ in Western society was fashionably 'camouflaged' by 'heredity, environment, inferiority complex, or any other of the fashionable narcotics of the conscience', Laws in TILSEY, G.E. (1929), Dan Crawford. Missionary and Pioneer in Central Africa, London, Oliphanths, p. VI. For alcohol, nerves and will, see also Cross, D.K. (1897), Health in Africa. A Medical Handbook for European Travellers and Residents, embracing a Study of Malarial Fever as it is found in British Central Africa, London, James Nisbet, pp. 69-71.

10 A revealing anecdote in missionary Alexander Hetherwick's biography highlights the centrality of will power among Laws's generation of educated missionaries. In 1883 when Henry Drummond, a popular scientist and prominent evangelical, was visiting Livingstonia, Hetherwick witnessed the struggle of 'will-power' between Laws and Drummond, a well-known hypnotist. Drummond tried to hypnotize Laws, but 'for once he had encountered a will-power stronger than his own.' LiVINGSTONE, W.P. (n.d. [1931]), A Prince of Missionaries. The Rev. Alexander Hetherwick, London, James Clarke, p. 32.

11 Laws to H.E. the Governor of Nyasaland 27 February 1912. MNA 47 /LIM/1/1/13, 845. 
brain and the nerves and spiritually in the soul. They kept dangerous passions and desires, as well as the general temperament, in check. Strengthening and conserving energy and power were the cornerstones of a healthy Christian life and were especially important for missionaries in Africa with its particular dangers to both body and mind. The diseases of moral transgression, particularly alcoholism and venereal disease, were seen as major threats to the missionary programme of 'regeneration'. Consequently, moral education and control were viewed as prerequisites for the practice of preventive medicine and the maintenance of health in Livingstonia. ${ }^{12}$

\section{MEETING OF MORAL AETIOLOGIES}

The Victorian missionary theory of health and illness that prevailed in Livingstonia had a strongly moral component, which underpinned the entire programme of 'regeneration' and the creation of the Christian community. In Livingstonia, sexual promiscuity and the consumption of alcohol were regarded as central threats to both individual and collective health, and the mission adopted an extremely intolerant policy towards anything connected to these 'vices'. Health arguments reinforced general missionary condemnation of polygamy, dancing and drinking in African societies.

The connection between moral transgression and illness was a prominent feature within explanations of ill health in the existing Central African medical culture. In their classic work, John Janzen and Terence Ranger emphasized that most pre-colonial African societies divided illness into two main categories: the 'diseases of God' and the 'diseases of Man'. The diseases of Man were the result of moral transgressions of various kinds. This category could include illnesses caused by a sufferer's own moral transgression and those caused by a malevolent witch. In this scheme, therefore, illnesses caused by ancestral spirits, spirits of the land, the breaking of taboos or witchcraft all belonged to the broad category of diseases of Man; these were usually treated by specialist healers. In contrast, diseases of God were not punishments sent by God: instead, they were similar to diseases attributed to 'natural' causes (or those seen to be caused by 'fate') in Western thought.

12 HoKKANEN (2007a), pp. 301-310; HoKKANEN and MANGAN (2006), pp. 12631265. Purity, strength and moral masculinity were, for Laws, crucial features of the ideal healthy African Christian man, who faced the dangers and temptations of colonial migrant labour. Laws to Eliya Foti Msuku, n.d. [1911]. MNA 47/LIM/1/1/13, 192. 
Such diseases were viewed as a tolerable part of life and largely herbal remedies were prescribed by ordinary people or healers. ${ }^{13}$

In encounters and interactions between African and missionary medicine, conflict was only one possible outcome. As Ranger has pointed out, African medical culture could easily accommodate Western medicine as a way of treating diseases of God or natural diseases. Furthermore, if certain diseases of man seemed to respond to missionary treatment, local aetiology could change: what was previously a disease of man would now be regarded a as disease of God that could be treated in a Western hospital. ${ }^{14}$

Theoretically, at least, the idea of 'moral diseases' could provide common ground between missionary and African theories of health and illness. Some similarities between Laws's theory of health and some aspects of pre-colonial medical theory in Malawi can be discerned. The idea that certain ailments or symptoms were the result of moral transgression could accommodate missionary beliefs that alcoholism and sexually transmitted diseases were manifestations of moral illness. Laws's ideas about divine punishment and degeneration corresponding to nature's laws were, in principle, not so far-removed from African beliefs that illnesses were caused by the moral failings of the individual or the community.

However, the similarities between the two moral aetiologies should not be over-emphasized. As Brian Morris notes, in Chewa theory of illness (as studied in Malawi in the 1980s) many diseases that follow from moral transgression result 'automatically' from the transgression without any spiritual agency. Such diseases can be prevented or treated very much like natural illnesses, apparently without lasting condemnation of the transgressor, ${ }^{15}$ quite unlike the position of the sinner, alcoholic or syphilitic degenerate in Victorian popular thought.

As recent scholarship has emphasized, medical culture, or medical system(s), in Central and Southeast Africa are, and have been, dynamic, pluralis-

13 JANZEN, J.M. (1978), The quest for therapy: medical pluralism in Lower Zaire, Berkeley, University of California Press, p. 8 and passim; RANGER, T. (1982), Medical Science and Pentecost: the Dilemma of Anglicanism in Africa. In SHEILS, W. (ed.), The Church and Healing, Oxford, Blackwell, pp. 333-365, p. 339.

14 RANGER (1982), pp. 339-340.

15 Morris, B. (1985), Chewa Conceptions of Disease - Symptoms and Etiologies, The Society of Malawi Journal, 38 (1), pp. 29-31. Furthermore, as Steven Feierman has argued, there are important differences between Western and African medical thought in diagnosis. In addition, comparison with science leads scholars away from the crucial questions of the problems Africans actually addressed when they spoke of healing and illness. See FEIERMAN, S. (2000), Explanation and Uncertainty in the Medical World of Ghaambo, Bulletin of the History of Medicine, 74, pp. 317-344, pp. 321, 328. 
tic and complex. ${ }^{16}$ However, it is important to note that Western medicine itself is not a homogenous monolith of secular, scientific practice, but a more pluralistic and heterogeneous entity. The binary categories of 'colonial' and 'indigenous' are increasingly being called into question. ${ }^{17}$ The history of nineteenth- and early twentieth- century missionary medicine is illustrative in this respect; in missionary medicine, religious and moral ideas and practices co-exist, albeit sometimes uneasily, alongside medico-scientific ideas. However, in order to fully understand the missionary ideas and practices of healing and health one must look beyond mission hospitals and dispensaries into the wider Christian community. Case studies of beer drinking and sexual morality can help us to understand the conflict, conversation and co-operation between missionaries and Africans in Livingstonia.

\section{BEER DRINKING}

Most Livingstonia missionaries condemned drinking absolutely. In their attitudes towards alcohol, the Scots of Livingstonia differed from many secular colonialists and other missionaries (though they tolerated the use of alcohol, particularly champagne, as medicine). The majority of Europeans in Central Africa were probably not total abstainers, and many thought that, in the tropics, alcohol was a necessary stimulant. Colonialists often drank European spirits and African beer, which earlier explorers like John Kirk had found refreshing. However, alcohol was a source of fear for many: the fear of European degeneration in Africa was largely a fear of demoralization, alcoholism and sexual debauchery. Physiologically, European degeneration in the tropical climate was frequently connected to the liver, and thus alcohol consumption. ${ }^{18}$

16 See, for example, the recent essays in LuEDKE, T.J. and WEST, H.G. (eds.) (2006), Borders \& Healers. Brokering Therapeutic Resources in Southeast Africa, Bloomington, Indiana University Press. For a further discussion of medical culture and medical systems, see HOKKANEN (2007a), pp. 1-6.

17 See, for example, VAughan, M. (1994), Healing and Curing: Issues in the Social History and Anthropology of Medicine in Africa, Social History of Medicine, 7 (2), pp. 183-295, pp. 287295; ERNST, W. (2007), Beyond East and West: From the History of Colonial Medicine to a Social History of Medicine(s) in South Asia, Social History of Medicine, 20 (3); SchumaKer, L., JeAter, D. and LuedKe, T. (2007), Introduction. Histories of Healing: Past and Present Medical Practices in Africa and the Diaspora, Journal of Southern African Studies, 33 (4), pp. 707-715.

18 (June 1900), The Aurora, pp 29-32; Copeland, R. (1928), Kirk on the Zambezi, Oxford, Clarendon Press, p. 141; on alcohol and exploration, see FABIAN, J. (2000), Out of Our 
The extreme attitude of Livingstonia missionaries stemmed from their background in late Victorian Scotland, where strong drink was seen as the primary cause of many urban social problems. ${ }^{19}$ The advocates of temperance frequently stressed the connections between drinking and disease, and they strove to prove that drunkenness developed into a disease that destroyed the brain and the body. However, from the medical point of view, it was difficult to determine the point at which excessive drinking could be termed a disease. Nevertheless, the medical authorities confirmed that the consumption of alcohol caused physiological damage and agreed that temperance was the first step towards curing the condition. Chronic alcoholism was regarded as a toxic disease of the nervous system. ${ }^{20}$

When missionaries encountered Africans drinking beer (often made from maize or millet), their initial condemnation was often no less harsh than it would have been when faced with whisky-drinking in Glasgow, and this could easily lead to cultural conflict. ${ }^{21}$ For many Africans the idea of abstaining from beer as a public health measure was distinctly alien and in some ways even contrary to local medical culture. The missionaries did not initially realize that beer brewed in Malawi was of variable strength and, furthermore, played a more significant and complex part in the life of a community than distilled spirits did in Britain. Beer was a foodstuff, as well as a drink, and was also used in many religious ceremonies, sometimes being presented to spirits as a sacrifice..$^{22}$ These sacrifices ensured the support and good will of the spirits and prevented ancestral wrath from causing misfortune and illness.

Minds. Reason and Madness in the Exploration of Central Africa, Berkeley, University of California Press. On liver, see JenNings, E.T. (2002), Curing the Colonizers: Highland Hydrotherapy in Guadalupe, Social History of Medicine, 15 (2), pp. 243, 248-249.

19 Laws's experiences of and attitudes towards drink were particularly severe. His biographer describes how the young medical student in the service of the Glasgow Medical Mission had to wrestle with a 'drunkard' in order to treat the man's wife and a newborn child - an experience that made Laws's condemnation of drink more harsh. LiVINGSTONE, W.P. (1921), Laws of Livingstonia, London, Hodder \& Stoughton, pp. 33-34.

20 See, for example, interview of Dr Clouston, Free Church of Scotland Monthly Record (hereafter FCSMR), December 1896, p. 305; CROSS (1897), p. 69.

21 Robert Laws Diary Journal entry for 20 January 1876. National Library of Scotland (hereafter NLS), MS. 7907.

22 Forster, P.G. (2003 [1989]), T. Cullen Young: Missionary and Anthropologist, Blantyre, CLAIM, p. 63; MCCRACKEN (2000), p. 298; MKANDAWIRE, J.B.C., The Tumbuka-Ngoni Relation in the Mzimba District, unpublished, Chancellor College History Department Seminar Paper, 1971-1972. 
Thus, beer was a significant feature of the local system of public health, and an all-out assault on beer drinking and beer brewing could be viewed as depriving people of their food (and an essential part of the farming culture) and placing them at risk of ancestral revenge and communal calamities. ${ }^{23}$

Missionaries eventually came to recognize some differences between beer and spirits and to acknowledge that beer was an important part of the local diet. However, they continued to argue that drinking caused a loss of discipline and self-control, the crucial elements of moral health. Furthermore, there was a real fear that under the influence of alcohol African Christians might question the authority and control of their European teachers. ${ }^{24}$ Indeed, hostility to missionary activity was frequently associated with beer drinking. ${ }^{25}$ The main danger of beer lay in the potential loss of control, both in the individual and in the collective. Total abstinence, as advocated by most Livingstonia missionaries, was seen as essential to the health of Europeans and Africans alike. ${ }^{26}$

The idea of beer as a cause of moral and physical retardation remained fixed in the minds of missionaries at Livingstonia, despite the increasing recognition of its role in the local diet. More significantly, following the first large-scale conversions among the Tonga and the Ngoni in the 1890s and 1900 s, some first-generation African converts formed an active anti-beer movement. This, in turn, provoked a strong reaction from some members of the wider community, who vigorously defended beer brewing and beer drinking against the attacks by Christians. The issue of beer drinking became a flashpoint for conflict within many local communities. ${ }^{27}$ The mission-educated

23 Livingstone (1921), pp. 66-68; MoIR, F.L.M. (1924), After Livingstone. An African Trade Romance, London, Hodder \& Stoughton, p. 22. Moir recalled that it was often 'under the influence of drink' that the 'big Arab chiefs' threatened Europeans; YounG, E.D. (1877), Mission to Nyassa, London, John Murray, p. 62.

24 Fields, K.E. (1985), Revival and Rebellion in Colonial Central Africa, Princeton, Princeton University Press.

25 Elmslie, quoted in FCSMR March 1903, p. 121; Elmslie 12 December 1906. NLS, Acc. 7548 D. 71 . Letters to the Livingstonia Sub-Committee 1907, p. 14; MCCRACKEN (2000), p. 305.

26 Fraser, A. (1914), A Missionary's wife among African Women, International Review of Missions, III, pp. 467-468.

27 The Aurora, December 1902, p. 100. Forster has noted how T.C. Young, despite recognizing the role of beer in religious ritual and its importance in collectivism and hospitality in Tumbuka society, did not mention at all the function of beer as payment for work in his anthropological writings. Forster suspects that association of beer drinking with hard work would have been such anathema to the Scottish Presbyterian readership that Young wrote nothing about this use of beer, a practice of which he almost certainly was aware. FORSTER (2003), p. 63. 
African Christian teacher-evangelists forcefully attacked beer drinking in the villages. As a result, the teachers were not welcomed in some villages, while in others they were actually driven away by force. ${ }^{28}$

Furthermore, as it expanded its sphere of operations, Livingstonia's strict policy on beer appeared to be in direct contrast to those of neighbouring missions (both Catholic and Protestant). ${ }^{29}$ The Bible did not provide unambiguous guidance for those missionaries and African Christians who discussed the issue of beer drinking. Jesus had turned water to wine, but without fermentation. In the Kasungu district, where Livingstonia and the Dutch Reformed Church competed with the Catholic missions, a popular song of the 1930s commemorated the beer debate from a Catholic perspective:

In the past the Protestants tricked us. You must not drink beer. Today we joined the Church. Today we joined the Catholic Church. ${ }^{30}$

(English translation of original chiChewa lyrics)

Nevertheless, the anti-beer movement among the Presbyterians of Northern Malawi was firmly established by the turn of the century. In contrast to most churches in the area, the communion wine taken at Livingstonia churches was - and remains - fruit juice. ${ }^{31}$

Some African Livingstonia graduates agreed fully with Laws's emphasis on will power, nerves and moral health for both individual and collective well-being, and advocated total abstinence on health grounds. In 1931, Fred Nyirenda, a Livingstonia-trained hospital assistant, published an article on the dangers of beer drinking in the mission periodical Vyaro na Vyaro. Nyirenda warned of the damage caused by alcohol to the nervous system, which led to the cumulative destruction of senses, self-control and morality. He claimed that strong drink was the cause of 40 per cent of all cases of insanity, 90 per

28 FCSMR, March 1903, p. 121; March 1904, p. 116.

29 Other Lands, January 1923, p. 63; MCCRACKEN (2000), p. 221; WRIGHT, M. (1971), German Missions in Tanganyika 1891-1941, Oxford, Clarendon Press, p. 158.

30 Quoted and translated in Linden, I. (1974), Catholics, Peasants and Chewa Resistance in Nyasaland 1889-1939, London, Heinemann, pp. 147-148.

31 Livingstonia Presbytery Minutes 19 October 1911. MNA/47/LIM/3/21; LiVINGSTONE (1921), p. 340. I remain grateful to the late Dr Andrew Ross for the reference to the use of fruit juice as communion wine. In Livingstonia Presbytery, beer drinking by a church member was a disciplinary offence, but in Blantyre, which followed the lines of the Established Church in Scotland, it was not. MCInTOSH, H. (1993), Robert Laws. Servant of Africa, Carberry, Handsel Press, pp. 166-167. 
cent of all cases of violence and 'much of the poverty in our land', further asserting that for every person driven insane because of drink there were twenty others who suffered from brain injuries, moral impairment or a limited capacity to work. ${ }^{32}$

However, there was also room for compromise. In 1922, and again in 1926, the issue of beer drinking was the subject of intense debate within the Mombera Native Association, a local political organization in Northern Malawi that brought together the mission-educated Christian elite and the Ngoni chiefs. ${ }^{33}$ In a compromise between abstainers and beer-drinkers, moderation rather than total abstinence was emphasized. The colonial authorities concurred in this, not seeing any particular danger in beer brewing and consumption on a small scale. ${ }^{34}$ Importantly, the Association brought to the fore not only the missionary medical view of beer as a cause of disease but also the idea of beer as a medium for 'bad medicines' - a central concern in African theories of illness. ${ }^{35}$

\section{SEXUAL MORALITY AND HEALTH}

For the Victorian Scottish missionaries, the most abhorrent African customs and practices were those connected to sexuality. This was highlighted in the missionaries' condemnatory attitudes towards most African dances. Some mission-educated African Christians adopted a puritanical attitude and condemned all dances that involved both men and women, sometimes even more fervently than the younger generation of missionaries. Importantly, as many scholars have pointed out, other prominent African Christians defended dancing against missionary intolerance: some doing so openly, others covertly. ${ }^{36}$

The fear of dancing in the medical missionary mind stemmed from the belief that, through unhealthy stimulation of the nerves and passions, dancing

32 NyiRendA, F. (1931), The Danger of Beer Drinking, Vyaro na Vyaro, November 1931, p. 6.

33 Minutes of the Mombera Native Association 28-31 July 1922. MNA S1/210/20.

34 Chief Secretary to Secretary, Mombera Native Association, 19 December 1922. MNA $\mathrm{S} 1 / 210 / 20$.

35 Minutes of the Mombera Native Association 26-27 May 1926. MNA S1/1365/24.

36 HoKkanen, M. (2005), 'Christ and the Imperial Games Fields' in South Central Africa - Sport and the Scottish Missionaries in Malawi, 1880-1914: Utilitarian Compromise, The International Journal of the History of Sport, 22 (4), pp. 745-769, pp. 759-761; MCCRACKEN (2000), p. 239; ThOMPSON, T.J. (1995), Christianity in Northern Malawi. Donald Fraser's Missionary Methods and Ngoni Culture, Leiden, Brill, p. 152. 
led to outbursts of uncontrolled sexuality, which was a primary danger to Christian moral health. Laws held that adultery was one of the worst sins that a Christian could commit, and in his view a person who had broken the Seventh Commandment was comparable to a patient who had lost a limb in an amputation - something in a person had been lost forever. Venereal disease was seen as the pathological expression of this sin. Adultery and polygamous marriage, along with beer drinking, were the most common causes for expulsion from the Church in early twentieth-century Livingstonia. ${ }^{37}$ Laws believed that responsibility for sexual behaviour lay firmly with men -European as well as African. For instance, in private, he strongly criticized the exploitation of African women by European colonialists in Southern Africa. In this respect, Laws can be numbered among the late nineteenth-century British social purists. ${ }^{38}$

Questions of sexual mores not only divided missionaries and Africans but also brought them together. Laws and other missionaries gradually began to admire the old moral code of Ngoni society in particular, while senior African chiefs and headmen occasionally joined forces with the mission in the condemnation of some new dances held to be 'immoral' by both groups. ${ }^{39}$ For their part, the largely Christian Ngoni elite utilized missionary language of sexual morality for their own ends in their dialogues with the colonial authorities. In 1921, the Mombera Native Association was gravely concerned about the moral health of society in Northern Ngoniland and the behaviour of European colonialists, many of whom had sexual liaisons with African women. ${ }^{40}$ In their critique of European sexual behaviour, the Association used

37 Livingstone (1921), pp. 268, 325-326; NCOZAna, S.S. (2002), The Spirit Dimension in African Christianity. A Pastoral Study among the Tumbuka People of Northern Malawi, Blantyre, CLAIM, pp. 150-151.

38 Laws to H.E. the Governor of Nyasaland 27 February 1912. MNA 47 /LIM/1/1/13, 845; Mort, F. (2000), Dangerous Sexualities. Medico-Moral Politics in England since 1830, London, Routledge, pp. 86-100 and passim; see also HYAM, R. (1992), Empire and Sexuality. The British Experience, Manchester, Manchester University Press; According to a commonly held Victorian view, warm climates were connected to the over-active sexuality of 'native' women. HAMmOND, D. and JABLOW, A. (1970), The Africa that Never Was. Four Centuries of British Writing About Africa, New York, Twayne Publishers, pp. 148-156. See also CollingHAM, E.M. (2001), Imperial Bodies. The Physical Experience of the Raj, c. 1800-1947, Cambridge, Polity Press; Vaughan, M. (1991), Curing their Ills. Colonial Power and African Illness, Stanford, Stanford University Press.

39 (1904), Report of the Second General Missionary Conference, pp. 18-20; Laws to Resident Magistrate, Chintechi, 16 November 1911. MNA 47 /LIM/1/1/13, 638.

40 Minutes of the Mombera Native Association 26-27 September 1921. MNA S1/210/20; MCCRACKEN (2000), pp. 316-317 and passim. Of the founding members of the Association, 
missionary rhetoric to denounce European sexual indulgence and co-habitation with African women.

In its response, the British administration placed all responsibility for the issue upon African society, and upon the behaviour of African women in particular. The Association fundamentally disagreed and, at a meeting in July 1922, argued that the responsibility lay with the colonial authorities and not with individual Africans or 'foreigners'. They claimed that the practice of cohabitation was brought to the district from elsewhere in the Protectorate by foreigners, whom the local population then imitated. For the sake of health and order, they appealed to the Governor to reconsider the issue. The administration's reply again emphasized sole African responsibility: parents simply should not let their daughters consort with European men. Furthermore, local communities were encouraged to regard a cohabiting woman as permanently disgraced and therefore unsuitable for marriage. ${ }^{41}$ The administration's emphasis upon the culpability of women was in direct opposition to the social purist views of Laws, as well as the Association's demands for effective legislation to ensure the protection of African women and society from concubinage, social disorder and venereal disease. ${ }^{42}$

\section{CONCLUSION}

For Robert Laws and his colleagues, Christianity was a regenerating force with the potential to transform individuals, families and societies totally. It was the key to saving Africa and Africans from degeneration and death. Christianity as a comprehensive force and the idea of holistic health — where the spiritual, mental and physical were linked through 'energy' - allowed

most were mission teachers. Many of the early members were elders in the church and the first President and the two secretaries had been representatives in the Presbytery for many years. CoOK, D.J. (1975), The Influence of Livingstonia Mission upon the Formation of Welfare Associations in Zambia, 1912-31. In RANGER, T. and WELLER, J. (eds.), Themes in the Christian History of Central Africa, London, Heinemann, p. 103.

41 Chief Secretary to Secretary, Mombera Native Association, 19 December 1922. MNA $\mathrm{S} 1 / 210 / 20$.

42 While in this case the Association unequivocally defended African women, in later discussions it was clear that the Association (whose members were exclusively senior men) blamed women for many illnesses, particularly venereal diseases. Association members called for a return to the old paternalistic order and Ngoni morality as a cure for such illnesses. See Minutes of the Mombera Native Association 26-27 May 1926. MNA S1/1365/24. 
Laws to intellectually bypass many of the prevailing social Darwinist notions of race and degeneration that increasingly influenced late Victorian science and medicine. However, Laws believed that the only alternatives to progress were stagnation and, ultimately, regression. These issues were discussed by the elite of the Overtoun Institution in the Livingstonia Literary Society, which in February 1905 debated the topic 'Were the people of Central Africa progressing, standing still, or retrograding when the Gospel came?'43 Unfortunately, the details of this particular debate remain obscure. However, the very fact that questions of progress versus degeneration were deemed to be publicly debatable suggests that missionary hegemonic ideas in this respect were openly contested by the mission-educated elite, as were questions of dancing, polygamy and the autonomy of African churchmen. ${ }^{44}$

The assessment of the impact of the missionary programme of regeneration and holistic health on the emerging African Christian community and the wider culture and society of Northern Malawi requires care. Popular missionary-influenced movements such as the anti-beer movement in Ngoniland could not have emerged simply because of missionary imposition or indoctrination but rather because something in the missionary assault against beer resonated with local social and material realities. Fields has noted how conversion to mission Christianity or the Watch Tower movement in SouthCentral Africa enabled people to challenge both the customary social order and colonial rule. ${ }^{45}$

The evidence in the cases of beer drinking and debates over sexual morality suggest that missionary ideas and policies clearly influenced the understanding of health, illness and morality in the emerging African Church and the Presbyterian Churches of Northern Malawi. However, in discussions about health and morality, as in debates about African medical practices, ${ }^{46}$ African Christians and local elites found ways to address local concerns - such as the use of beer as a medium for 'bad medicines' and the dangers posed to moral health by colonial rule - and were also able to appropriate the missionary language of health and morality and use it for their own purposes.

43 A syllabus for the Livingstonia Literary Society, $7^{\text {th }}$ Session, 1905. NLS, Acc. 7548,

D. 71. Letters to the Livingstonia Sub-Committee 1905, p. 42.

44 MCCRACKEN (2000), pp. 239-242 and passim.

45 FieldS (1985).

46 HoKkanen, M. (2007b), Quests for Health and Contests for Meaning: African Church Leaders and Scottish Missionaries in the Early Twentieth-Century Presbyterian Church in Malawi, Journal of Southern African Studies, 33 (4), pp. 733-750. 
Moral transgression as a cause of disease, in their interpretations, was not only the result of the action of an individual sinner, who then became a sufferer, but could also be caused by outside agencies such as poisoners and sorcerers or foreign abusers of African women. Missionaries failed to recognize the first of these concerns and were incapable of publicly addressing the second in an open critique of colonial rule. The 'moral hygiene' that emerged in the Presbyterian communities of Northern Malawi was one outcome of a long process of communication and interaction between Scottish missionaries and African Christians. ${ }^{47}$

Fecha de recepción: 31 de octubre de 2007.

Fecha de aceptación: 30 de septiembre de 2008.

47 In some respects, echoes of these past debates can still be discerned in Malawi today. In 2004, Ngoni chiefs from Northern Malawi claimed that their forefathers — practising Christians - had obtained special licences from the first missionaries to drink beer and marry several wives. On this basis, these chiefs challenged the Presbyterian Church leaders who insisted that the chiefs were under the same obligations as other members of the Church. 